\title{
Trajektoria zmian przedsiębiorczości społecznej w Polsce ${ }^{1}$
}

\begin{abstract}
Agnieszka Pacut*
Streszczenie: W artykule skoncentrowano się na przedstawieniu trajektorii zmian przedsiębiorczości społecznej w Polsce, akcentując temporalny i procesualny charakter zjawiska. Celem artykułu jest opis przebiegu rozwoju przedsiębiorczości społecznej w perspektywie makro oraz identyfikacja na tej podstawie czynników, które mogą determinować jej rozwój, stanowiąc tym samym przedmiot dalszej refleksji teoretycznej. Tekst bazuje na kwerendzie literatury z zakresu przedsiębiorczości społecznej i jej analizie. Rozważania prowadzą do wniosku, że w analizie zjawiska ważne miejsce ma dziedzictwo historyczne oraz czynniki prawno-instytucjonalne. Tym samym wskazano na rolę otoczenia instytucjonalnego jako ważnej zmiennej determinującej rozwój przedsiębiorczości społecznej.
\end{abstract}

Słowa kluczowe: przedsiębiorczość społeczna, rozwój, trajektoria zmian, czynniki rozwoju, otoczenie instytucjonalne.

\section{Wprowadzenie}

Przeprowadzone dotychczas badania i analizy potwierdzają istotną rolę otoczenia (context, environment, eco-systems) dla rozwoju przedsiębiorczości społecznej (PS) [Kerlin, 2017; Urbano et al., 2017; Roy et al., 2015; Hoogendoorn, Hartog, 2011]. W tym obszarze podejmowane są prace mające na celu przedstawienie i ocenę roli środowiska w ujęciu narodowym [np. Urbano, Toledano, Soriano, 2010] oraz międzynarodowym [np. Kerlin, 2013; 2017]. W 2016 r. Fundacja Thomson Reuters opublikowała ranking, przeprowadzony wśród 45 krajów, w tym w Polsce, który oceniał środowisko dla działalności przedsiębiorców społecznych. Najlepsze warunki dla rozwoju tego typu aktywności tworzone były w Stanach Zjednoczonych, Kanadzie, Wielkiej

\footnotetext{
Publikacja została przygotowana w projekcie "Kapitał ludzki jako podstawowy czynnik zakorzenienia globalnych usług biznesowych" nr: 059/WGAP-KGP/01/2018/S/8059, dofinansowanym z dotacji Ministerstwa Nauki i Szkolnictwa Wyższego dla Wydziału Gospodarki i Administracji Publicznej Uniwersytetu Ekonomicznego w Krakowie na utrzymanie potencjału badawczego.
}

Brytanii. Dalej wskazano: Singapur, Izrael, Chile, Koreę Południową, Hongkong, Malezję. Ranking zamyka Francja [The best countries, 2016]. Pomimo pewnych ustaleń w tym zakresie, w dalszym ciągu jest to obszar słabo poznany, zwłaszcza w zakresie instytucjonalnych wzorców kształtujących działalność przedsiębiorstw społecznych [Kerlin, 2017, s. 3]. W opinii wielu badaczy prowadzone obecnie rozważania nad przedsiębiorczością społeczną muszą uznać, a nawet położyć szczególny nacisk na kontekst kulturowy, społeczny, historyczny i sytuacyjny, w których to zjawisko rozwija się w poszczególnych krajach [Lehner, 2012; Kerlin, 2017].

Ze względu na powyższe przedmiotem zainteresowania w artykule uczyniono trajektorię zmian przedsiębiorczości społecznej w Polsce. Przyjęcie tej perspektywy umożliwiło ukazanie przebiegu zjawiska, a na tym

\footnotetext{
* Agnieszka Pacut

Katedra Gospodarki Publicznej

Uniwersytet Ekonomiczny w Krakowie

ul. Rakowicka 16, 31-510 Kraków

e-mail:agnieszka.pacut@uek.krakow.pl
} 
tle identyfikację czynników jego rozwoju w Polsce.

\section{Periodyzacja rozwoju przedsiębiorczości społecznej w Polsce}

Analizując trajektorię zmian przedsiębiorczości społecznej w Polsce należy wskazać na przesłanki pojawienia się tego zjawiska. W szczególności są to uwarunkowania związane z występowaniem problemów społecznych (bezrobocia, wykluczenia społecznego), wynikające z przemian politycznych, ustrojowych, ekonomiczno-społecznych, a także dotyczące pojawienia się nowych ryzyk społecznych (takich jak: starzenie się ludności, prekariat, nowe ubóstwo itp.) [por. Leś, 2005; 2013]. Jednocześnie należy zwrócić uwagę na aktywność decydentów publicznych, polegającą na określeniu sposobów przeciwdziałania ww. problemom, w tym za pośrednictwem rozwiązań (narzędzi) oferowanych w ramach ustawy o zatrudnieniu socjalnym, ustawy o działalności pożytku publicznego i o wolontariacie, ustawy o spółdzielniach socjalnych i innych [Leś, 2005]. Dalej należy docenić istotną rolę integracji europejskiej, która dała asumpt do upowszechniania programów i unijnych priorytetów w zakresie gospodarki społecznej - w wymiarze koncepcyjnym, programowym i finansowym. W ana- lizie nie można pominąć źródeł i rodowodu działań o charakterze społecznym podejmowanych przez obywateli w kraju w różnych formach organizacyjno-prawnych.

Do takiego ujęcia tematu nawiązują periodyzacje rozwoju przedsiębiorczości społecznej wypracowane przez badaczy krajowych (por. tabela 1). Ukazują one rodowód i przebieg tego typu aktywności w Polsce. Każdy z autorów wyodrębnił określone fazy, traktując rozwój zjawiska jako ciąg następujących po sobie etapów. Każdorazowo analizy usytuowano w kontekście historycznym, politycznym i społeczno-gospodarczym. Rozbieżności w przedstawionych typologiach dotyczą historycznych źródeł przedsiębiorczości społecznej oraz kamieni milowych w rozwoju zjawiska.

Dotychczasowe ustalenia wykorzystano do omówienia trajektorii zmian przedsiębiorczości społecznej w Polsce. Termin trajektoria został tu użyty jako metafora ukazująca temporalny i procesualny charakter zjawiska przedsiębiorczości społecznej [Konecki, 2000]. Równocześnie należy dodać, iż termin PS będzie rozumiany w artykule jako "mechanizm tworzenia przedsiębiorstw społecznych i jako bezpośrednią metodę produkcji dóbr i usług przez stowarzyszenia i fundacje oraz inne formy nowej gospodarki społecznej" [Leś, 2008, s. 40; Rymsza, 2010].

\section{Tabela 1. Periodyzacje rozwoju przedsiębiorczości społecznej w Polsce - wybrane ujęcia}

\begin{tabular}{|c|c|}
\hline Etapy & Charakterystyka etapu \\
\hline \multicolumn{2}{|r|}{ Ciepielewska-Kowalik et al. [2015] } \\
\hline $\begin{array}{l}\text { Pierwszy okres: przed drugą } \\
\text { wojną światową }\end{array}$ & $\begin{array}{l}\text { - Typy podmiotów: stowarzyszenia, fundacje i inne organizacje wolontarystyczne, } \\
\text { spółdzielnie } \\
\text { - Funkcje: oferowanie wsparcia ubogim i potrzebującym grupom społecznym, zaspakajanie } \\
\text { ich potrzeb; wspieranie rozwoju gospodarczego kraju poprzez przejęcie roli nieistniejących } \\
\text { instytucji publicznych, podtrzymywanie ducha narodowego, zapewnienie społecznego } \\
\text { i edukacyjnego wsparcia obywatelom w okresie zaborów i w okresie międzywojennym } \\
\text { - Wyróżniki: znaczący udział ruchu spółdzielczego w potencjale ekonomicznych kraju }\end{array}$ \\
\hline
\end{tabular}




\begin{tabular}{|c|c|}
\hline Etapy & Charakterystyka etapu \\
\hline $\begin{array}{l}\text { Drugi okres: działanie państwa } \\
\text { komunistycznego } \\
\text { (1945-1989) }\end{array}$ & $\begin{array}{l}\text { - Znaczący wpływ partii komunistycznej na działania organizacji obywatelskich (fundacji, } \\
\text { stowarzyszeń, związków i i in.) oraz sektora spółdzielczego (poprzez ograniczenie autonomii, } \\
\text { nadzór nad działalnością programową, przejęcie majątku, włączenie spółdzielni do } \\
\text { gospodarki państwowej zgodnie z ideą kolektywizacji i in.) }\end{array}$ \\
\hline Trzeci okres: po 1989 r. & $\begin{array}{l}\cdot 1989-1995 \\
\cdot 1996-2002 \\
\cdot 2003-\text { obecnie }\end{array}$ \\
\hline \multicolumn{2}{|r|}{ Praszkier, Zabłocka-Bursa, Józwik [2014] } \\
\hline $\begin{array}{l}\text { 1918-1939: od chwili odzyskania } \\
\text { niepodległości i pełnej demokracji } \\
\text { do drugiej wojny światowej }\end{array}$ & $\begin{array}{l}\text { - Powstawanie inicjatyw spółdzielczych, w tym nastawionych na rozwój wiejskich } \\
\text { społeczności (np. Lisków) }\end{array}$ \\
\hline $\begin{array}{l}\text { 1939-1945: okres okupacji } \\
\text { niemieckiej }\end{array}$ & - Zaniechanie działań w obszarze gospodarki, w tym gospodarki społecznej \\
\hline $\begin{array}{l}\text { 1945-1980: okres powojenny, } \\
\text { dominacja sowiecka }\end{array}$ & $\begin{array}{l}\text { - Gospodarka sterowana odgórnie } \\
\text { - Inicjatywy oddolne obywateli oraz działania przedsiębiorcze postrzegane jako wrogie } \\
\text { państwu } \\
\text { - Kontrola sprawowana przez władze państwowe uniemożliwiała powstawanie niezależnych, } \\
\text { oddolnych organizacji }\end{array}$ \\
\hline $\begin{array}{l}\text { 1981-1989: podziemna Solidar- } \\
\text { ność }\end{array}$ & $\begin{array}{l}\text { - Potrzeba niepodległości i demokracji wśród społeczeństwa osiągnęła krytyczny moment } \\
\text { - Działalność podejmowana w podziemiu bazowała na zaangażowaniu i przedsiębiorczości } \\
\text { obywateli } \\
\text { - Wzrost inicjatywności obywateli, wzmocnienie sfery obywatelskiej }\end{array}$ \\
\hline $\begin{array}{l}\text { 1989 - do chwili obecnej: po } \\
\text { odzyskaniu niepodległości i } \\
\text { przywróceniu demokracji }\end{array}$ & $\begin{array}{l}\text { - Przemiany polityczne, społeczne i gospodarcze } \\
\text { - Eksplozja oddolnych inicjatyw społecznych i gospodarczych } \\
\text { - Uchwalenie aktów prawnych konstytuujących działalność organizacji gospodarki społecznej } \\
\text { (np. Konstytucja RP, ustawa o działalności pożytku publicznego i o wolontariacie, ustawa } \\
\text { o zatrudnieniu socjalnym, ustawa o spółdzielniach socjalnych) } \\
\text { - Rola wsparcia finansowego w wyodrębnieniu sektora przedsiębiorczości społecznej (Unii } \\
\text { Europejskiej i innych organizacji, np. Ashoka) }\end{array}$ \\
\hline \multicolumn{2}{|r|}{ Rymsza [2007b, s. 2-6]; Kaźmierczak [2007, s. 105-106] } \\
\hline $\begin{array}{l}\text { Przełom XIX i XX w. i okres } \\
\text { międzywojenny: } \\
\text { stara fala ekonomii społecznej }\end{array}$ & $\begin{array}{l}\text { - Cechy charakterystyczne: wypełnianie nisz nieatrakcyjnych dla rynku komercyjnego, } \\
\text { uczestnictwo oparte na zasadzie wzajemności, oddolny i samowystarczalny charakter } \\
\text { inicjatyw, brak przywilejów prawnych dla inicjatyw, istotna rola liderów w tworzeniu } \\
\text { i upowszechnianiu inicjatyw } \\
\text { - Problem społeczny, na który reaguje: wyzysk, alienacja } \\
\text { - Efekty: osłabienie konfliktu klasowego } \\
\text { - Typowe podmioty: spółdzielnie, towarzystwa ubezpieczeń wzajemnych, związki kredytowe }\end{array}$ \\
\hline $\begin{array}{l}\text { XXiXXI w.: nowa fala ekonomii } \\
\text { społecznej }\end{array}$ & $\begin{array}{l}\text { - Cechy charakterystyczne: obudowanie przez inicjatywy ekonomii społecznej „normalnego } \\
\text { rynku”, sprzężenie oddolnych działań obywatelskich z aktywną rolą państwa, wsparcie } \\
\text { publiczne inicjatyw w postaci zatrudnienia socjalnego i subsydiowanego, inicjatywy } \\
\text { są zorientowane na korzyść wzajemną (członków) oraz szerzej korzyść społeczną } \\
\text { (tj. społeczności lokalnych, środowisk marginalizowanych) } \\
\text { - Problem społeczny, na który reaguje: bezrobocie, wykluczenie } \\
\text { - Typowe podmioty: spółdzielnie socjalne, organizacje pozarządowe prowadzące działalność } \\
\text { gospodarczą }\end{array}$ \\
\hline
\end{tabular}

Źródła: opracowanie własne na podstawie wskazanych źródeł. 
W nawiązaniu do dotychczasowych ustaleń rozwój PS w Polsce można odczytać i analizować jako proces odbywający się w trzech podokresach, tj.: 1) do 1989 r., 2) 1989-2003, 3) 2004 - współcześnie. Cezurę czasową w proponowanej periodyzacji wyznaczyły dwie daty: 1989 r. jako historyczny moment przemian społeczno-gospodarczych w Polsce, który z jednej strony zamyka, z drugiej zaś otwiera na nowo sferę aktywności obywatelskiej. Równocześnie wskazano na 2004 r. jako moment wejścia Polski do Unii Europejskiej, co wiązało się z uruchomieniem znacznych środków finansowych umożliwiających testowanie i realizację różnorodnych działań łączących cele społeczne i ekonomiczne dla rozwiązywania problemów społecznych i zaspakajania potrzeb obywateli.

\section{2. Źródła i tradycje działań obywatelskich i wspólnotowych w Polsce do 1989 r.}

Od najdawniejszych czasów jednostki i grupy obywateli podejmowały w Polsce działania mające na celu samopomoc, samoobronę lub zapewnienie realizacji różnych potrzeb, wykorzystując do tego celu różne formy organizacyjne - od nieformalnych wspólnot przez fundacje i stowarzyszenia aż do spółek gospodarczych i spółdzielni. W tym kontekście za T. Kaźmierczakiem można stwierdzić, iż praktyka działania z obszaru PS żadną miarą nie jest zagadnieniem nowym [Kaźmierczak, 2007, s. 93] - typem aktywności, który został rozpoznany w XX czy XXI wieku. W krajowej literaturze przedmiotu raczej wskazuje się na ponowne odkrycie fenomenu przedsiębiorczości społecznej [Rymsza, 2007a], niż wymyślenie tego typu działalności. W tym kontekście sięga się do lat 80. XX wieku - ruchu społecznego Solidarność, ale także korzeni aktywności obywatelskiej z czasu zaborów oraz międzywojnia, w których wspólnotowe i wzajemnościowe formy gospodarki odgrywały ważną rolę jako mechanizm politycznej i społecznej emancypacji [Manifest, 2008].
Analizując dorobek organizacji obywatelskich począwszy od okresu Średniowiecza do czasów III Rzeczypospolitej E. Leś udowodniła, iż przyczyniły się one nie tylko do przetrwania i rozwoju społeczeństwa polskiego, służąc podtrzymywaniu solidaryzmu społecznego, samowystarczalności, promowaniu awansu społecznego, kulturalnego i cywilizacyjnego Polski [Leś, 2001, s. 16]. Dostrzec należy również wyraźne przemiany w działalności organizacji obywatelskich - prowadzonych w formie fundacji i stowarzyszeń - w zakresie ewolucji celów, sposób działania, w tym finansowania aktywności podejmowanej oddolnie przez obywateli. Na marginesie, J. Defourny i P. Develtere stwierdzili, iż źródła i pierwowzory gospodarki społecznej są tak stare, jak formy zrzeszania się obywateli. Rozwój gospodarki społecznej przebiegał na przestrzeni wieków równolegle z kształtowaniem się swobody stowarzyszenia się. Jako przykład można podać starożytne, średniowieczne, oświeceniowe źródła gospodarki społecznej w postaci bractw, cechów, instytucji dobroczynnych, fraterni, towarzystw handlowych, stowarzyszeń mistrzowskich itp. Dopiero na przełomie XIX iXX w. stworzono ramy prawne dla podstawowych form gospodarki społecznej, takich jak: spółdzielnie, towarzystwa wzajemnościowe i organizacje non-profit [Defourny, Develtere, 2008, s. 16-17]. W takim duchu można odczytać i poddać analizie dzieje dobroczynności, działań kooperatywnych, wzajemnościowych w Polsce, stwierdzając, iż przedsięwzięcia społeczne mają genezę tak długą jak problemy społeczne, które rozwiązują [Płonka 2015, s. 86-88]. Tradycje tego typu działalności w literaturze krajowej omawiają m.in.: A. Piechowski [2008; 2013] i P. Frączak [2006].

\section{Doświadczenia z lat 1989-2003}

Drugi ze zidentyfikowanych okresów przypada zasadniczo na lata 90. XX w., czyli czas intensywnych przemian społecznych i gospodarczych, połączonych ze zmianą ustroju 
w Polsce. Transformacja oznaczała wyzwania i zmiany dla różnych aktorów w gospodarce, w tym również dla obywateli oraz tworzonych przez nich organizacji. W latach 90. XX w. miał miejsce zryw aktywności obywateli stanowiący odpowiedź na wyzwania, potrzeby oraz aspiracje społeczeństwa polskiego [Leś, 2001]. W opinii części badaczy krajowych w Polsce w latach 90. XX w. doszło do uformowania się takiego modelu państwa, który nie sprzyjał rozwojowi podmiotów społeczeństwa obywatelskiego i ich uczestnictwu w politykach publicznych [Zybała, 2015, s. 35-53; Kaźmierczak, Rymsza, 2007, s. 11-13; Rymsza, 2007b, s. 2-8; Rymsza, 2007a, s. 175-189]. Z jednej strony państwo zachowało ambicje do kontroli społeczeństwa i jego organizacji przy niskim poziomie zdolności do tworzenia ładu społecznego i zaspokajania potrzeb społecznych, stając się przy tym obszarem silnej penetracji przez grupy interesów oraz ich zasadniczego wpływu na politykę publiczną [Zybała, 2015 , s. 39]. Z drugiej zaś strony, ówczesny dyskurs polityczny w zakresie modelu państwa opiekuńczego cechował się silnym nastawieniem na redukcję funkcji socjalnych państwa. W efekcie zakorzenił się model polityki społecznej, który nie przewidywał uspołeczniania ryzyk socjalnych [ibidem, s. 40]. W praktyce oznaczało to marginalizację roli, doświadczeń oraz możliwości udziału organizacji obywatelskich w procesie tworzenia i implementacji polityk publicznych. W opinii części badaczy krajowych rozwiązania instytucjonalne nowego ładu ustrojowego wypracowane w latach 90. „ignorowały i utrudniały rozwój" organizacji i rozwiązań gospodarki społecznej w Polsce, przyczyniając się m.in. do regresu sektora spółdzielczego [Śliwiński, 2013, s. 113-118]. Uzasadniając to stanowisko wskazać należy na profil przemian ustrojowych - prorynkowy i indywidualistyczny, pozbawiony wizji ładu społecznego oraz polityki włączającej sektor społeczny w doko- nujące się w kraju reformy [Rymsza, 2007a]. Funkcja polityki społecznej została sprowadzona do działań osłonowych, hamowała rozwijanie aktywizujących metod mieszczących się w nurcie przedsiębiorczości społecznej. Podobnie ma się sprawa z jednym z filarów przedsiębiorczości społecznej - spółdzielczością, która została potraktowana jako element ładu komunistycznego. W efekcie przeciwstawienia spółdzielni gospodarce wolnorynkowej, w opinii E. Leś [2006, s. 6], nie zostały one wykorzystane ani jako mechanizm restrukturyzacji usług społecznych i rozwoju lokalnego, ani jako możliwa z form prywatyzacji. Podsumowując ten okres M. Rymsza [2007a, s. 189] stwierdził: „Ekonomia społeczna «pachniała socjalizmem», jej instrumenty i instytucje nie mieściły się w ówczesnym katalogu skutecznego instrumentarium rynku. (...) pozostała (ona) przez całą dekadę lat 90. poza głównym nurtem zmian instytucjonalnych". Pomimo tej krytycznej oceny początku lat 90 . XX w. należy przywołać rozwiązania prawne, które poza ustawami określającymi działalność fundacji i stowarzyszeń, stworzyły ramy dla rozwoju szeroko rozumianej sfery przedsiębiorczości społecznej. Kluczowe znaczenie w tym zakresie miały takie akty prawne jak: ustawa z dnia 13 czerwca 2003 r. o zatrudnieniu socjalnym, ustawa z dnia 24 kwietnia 2003 r. o działalności pożytku publicznego i o wolontariacie, określana mianem „małej konstytucji sektora obywatelskiego w Polsce". Ostatni z aktów prawnych miał szczególne znaczenie dla funkcjonowania organizacji pozarządowych, przyczynił się do instytucjonalizacji kontaktów pomiędzy organizacjami obywatelskimi a administracją publiczną szczebla rządowego i samorządowego, wprowadził rozwiązania finansowe, które ukształtowały relacje międzysektorowe, precyzując zasady i formy tej współpracy. Ze względu na powyższe, 2003 r. można przyjąć jako cezurę czasową zamykającą pierwszy etap rozwoju PS. 


\section{Doświadczenia z lat 2004-2018}

Trajektorię rozwoju przedsiębiorczości społecznej od 2004 r. można rozpatrywać w odniesieniu do realizacji krajowej polityki publicznej w powiązaniu z programowaniem Unii Europejskiej w Polsce (w latach: 20042006, 2007-2013, 2014 - obecnie).

Ramy formalne dla tego typu aktywności wyznaczały dokumenty określające priorytety i cele strategiczne administracji. Zostały one zdefiniowane w dokumentach takich jak: Strategia Rozwoju Kraju 2020, Długookresowa Strategia Rozwoju Kraju Polska 2030. Trzecia Fala Nowoczesności, Strategia Rozwoju Kapitału Społecznego, Krajowy Program Przeciwdziałania Ubóstwu i Wykluczeniu Społecznemu 2020. Aktualnie ramy dla ekonomii społecznej w Polsce wyznacza Strategia na Rzecz Odpowiedzialnego Rozwoju do roku 2020 (z perspektywą do 2030 r.). Przykładem dokumentu stanowiącego instrument wykonawczy polityki rozwoju jest Krajowy Program Rozwoju Ekonomii Społecznej przyjęty w 2014 r. uchwałą Rady Ministrów, wydaną na podstawie ustawy o zasadach prowadzenia polityki rozwoju z 6 grudnia 2006 r. Niniejszy dokument stanowi przykład przełożenia rozwiązań wspólnotowych na poziom krajowy. Należy dodać, iż jego przyjęcie było jednym z warunków ex-ante, które musiała spełnić Polska w perspektywie finansowej na lata 2014-2020 [Sprawozdanie z realizacji, 2017]. Jednocześnie od 2017 r. trwają prace nad aktualizacją programu. W ww. dokumentach PS rozpatruje się jako narzędzie prowadzące do trwałego i zrównoważonego rozwoju, spójności społeczno-gospodarczej, przeciwdziałania wykluczeniu społecznemu i tworzenia miejsc pracy.

Analiza M. Małeckiej-Łyszczek dotycząca miejsca ekonomii społecznej w systemie źródeł prawa RP w latach 2003-2016 wykazała między innymi, iż na poziomie decydentów dostrzeżono narzędzia i potencjał ekonomii społecznej, zaś odrębną kwestią jest przejście od stanu postulowanego do praktycznego wykorzystania potencjału podmiotów ekonomii społecznej w Polsce [Małecka-Łyszczek, 2017, s. 81-148].

Programy finansowane ze środków UE oraz krajowych, przeznaczone na utworzenie i prowadzenie podmiotów w obszarze przedsiębiorczości społecznej, odegrały istotną rolę w promocji nowatorskich rozwiązań w zakresie aktywnej integracji, tworzenia miejsc pracy i przeciwdziałania wykluczeniu społecznemu w Polsce. Podkreślić należy skalę przeznaczonych na ten cel środków finansowych, która była nieporównywalna w stosunku do innych dostępnych dotychczas źródeł. Umożliwiła ona realizację projektów o charakterze testującym, innowacyjnym (w ramach PIW EQUAL), jak i kontynuację tego sposobu działania i myślenia o rozwiązywaniu problemów społecznych w kolejnych perspektywach finansowych UE.

Równocześnie realizację programów finansowych ze środków UE i krajowych cechowały m.in.: koncentracja na kwestiach formalnych i proceduralnych, a nie uzyskanych rezultatach, ograniczona elastyczność w dostosowaniu zapisów programów (operacyjnych i wdrożeniowych) do zmieniających się uwarunkowań i potrzeb odbiorców wsparcia. Rozwojowi przedsiębiorczości społecznej nie służyło również wąskie myślenie o sposobie jej wspierania, przejawiające się koncentracją na działalności ośrodków wsparcia ekonomii społecznej oraz małą dywersyfikacją oferowanych rozwiązań finansowych [Gosk 2010; Guz, Mituś, 2010; Stronkowski et al., 2013].

W efekcie czego ten sposób wdrażania wsparcia publicznego ograniczał możliwości powstawania i rozwoju zróżnicowanych co do formy i sposobu działania podmiotów przedsiębiorczości społecznej, jak również utrudniał profesjonalizowanie oferty działającym organizacjom. Reguły wdrażania wsparcia publicznego utrudniały działanie podmiotom otoczenia, reagowanie na potrzeby odbiorców w sposób elastyczny i dopasowany do ich możliwości i sytuacji. 


\section{Podsumowanie}

Trajektorię zmian przedsiębiorczości społecznej w Polsce przedstawiono identyfikując trzy okresy rozwoju zjawiska, zilustrowane na schemacie 1. Pierwszy - do 1989 r. - ukazuje historyczne źródła zjawiska, w tym formy gospodarowania, które poprzez kooperację i samopomoc miały zapewnić możliwie jak najlepszą sytuację społeczną, ekonomiczną, polityczną obywateli, udziałowców, użytkowników. Drugi - od 1989 r. do 2003 r. - wiąże się z odbudową inicjatyw przedsiębiorczości społecznej w Polsce w nowych realiach ustrojowych, politycznych i społeczno-gospodarczych. Trzeci obejmujący okres od 2004 r. do dziś - wiąże się z testowaniem rozwiązań w zakresie przedsiębiorczości społecznej i poszukiwaniem polskiego modelu przedsiębiorczości społecznej.

Przeprowadzona analiza wskazuje, iż trajektoria rozwoju przedsiębiorczości społecznej w Polsce jest warunkowana czynnikami politycznymi, społecznymi i historycznymi, zaś współcześnie jest ona silnie uzależniona od unormowań prawnych i procedur związanych z programowaniem Unii Europejskiej.

\section{Schemat 1. Periodyzacja rozwoju przedsiębiorczości społecznej w Polsce}

do $1989 \mathrm{r}$

Źródła i tradycje działań obywatelskich
2004 r. - współcześnie

Testowanie rozwiązań i poszukiwanie własnego modelu przedsiębiorczości społecznej

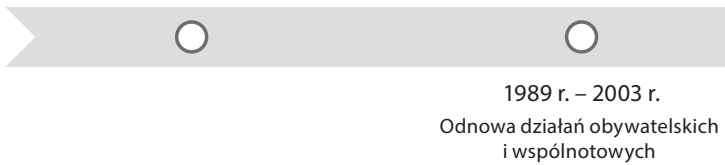

Źródło: opracowanie własne.

Przedstawione rozważania wskazują, iż przedsiębiorczość społeczna ma w Polsce długą tradycję, której źródła sięgają ruchu spółdzielczego i odnoszą się do aktywności filantropijnej i charytatywnej podejmowanej od wieków przez obywateli. Historia ma znaczenie (history matters) i stanowi ważną zmienną kontekstową, która wzbogaca wyjaśnianie przemian porządku społecznego w tym zakresie. Rola, charakter i uwarunkowania aktywności obywatelskiej ulegały zmianom, niemniej jednak stanowią one pierwowzór i kontekst dla działań wspólnotowych podejmowanych współcześnie [Leś, 2001; Frączak, 2006; Piechowski, 2008].

Dalej należy wskazać na działalność decydentów publicznych związaną z przyjętym kierunkiem rozwiązywania problemów społecznych. Analizując uwarunkowania rozwoju przedsiębiorczości społecznej należy podkreślić rolę otoczenia prawnego, które tworzyło ramy formalne i finansowe dla działań z obszaru PS. Zasadniczą rolę spełniały tu doku- menty tworzone na poziomie unijnym, które wyznaczały ramy, kierunek, a także nadawały znaczenie działalności przedsiębiorczej o celu społecznym. Strategie, plany, programy tworzone na poziomie krajowym stanowiły instrument służący realizacji polityki rozwoju społeczno-gospodarczego kraju, w tym regulowały warunki i procedury wykorzystania środków finansowych pochodzących z budżetu Unii Europejskiej. Tym samym determinowały one warunki powstawania i działania podmiotów przedsiębiorczości społecznej, jak również organizacji tego procesu.

Ze względu na powyższe jednym z potencjalnie istotnych kierunków analizy może być rozpatrywanie przedsiębiorczości społecznej w perspektywie instytucjonalnej. W szczególności warto zwrócić uwagę na ekonomiczny odłam tego nurtu, wskazując na potencjał nowej ekonomii instytucjonalnej (NEI). NEI umieszcza problemy funkcjonowania gospodarki i jej podmiotów w szerszym kontek- 
ście, przełamując bariery oddzielające system ekonomiczny od innych elementów otoczenia - społecznego, kulturowego, politycznego. Ukazuje ona wpływ czynników pozaekonomicznych (społecznych, historycznych, kulturowych, prawnych) na funkcjonowanie rynku, a jednocześnie poddaje je analizie ekonomicznej [Wilkin, 2016, s. 105].

Wrażliwość NEl na kontekst (społeczny i historyczny), a przede wszystkim uznanie krytycznej roli środowiska (otoczenia) w funkcjonowaniu aktorów społecznych, politycznych

\section{Literatura}

Ciepielewska-Kowalik A., Pieliński B., Starnawska M., Szymańska A. (2015). "Social Enterprise in Poland: Institutional and Historical Context", ICSEM Working Papers, No 11, Liege: The International Comparative Social Enterprise Models.

Defourny J., Develtere P. (2008). „Ekonomia społeczna: ogólnoświatowy trzeci sektor", w: J.J. Wygnański (wybór tekstów), Przedsiębiorstwo społeczne. Antologia kluczowych tekstów (s. 13-41). Warszawa: Fundacja Inicjatyw Społeczno-Ekonomicznych.

Estrin S., Mickiewicz T., Stephan U. (2013). „Entrepreneurship Social Capital, and Institutions: Social and Commercial Entrepreneurship across Nations", Entrepreneurship Theory and Practice, Vol. 37(3), s. 479504.

Frączak P. (2006). „,Szkic do historii ekonomii społecznej w Polsce", w: Raport Otwarcia projektu "W poszukiwaniu polskiego modelu ekonomii społecznej". Warszawa: Fundacja Inicjatyw Społeczno-Ekonomicznych.

Gosk I. (2010). „Wsparcie ekonomii społecznej w Programie Operacyjnym Kapitał Ludzki", Trzeci Sektor, nr 21, s. 44-50.

Hoogendoorn B., Hartog C. (2011). Prevalence and determinants of social entrepreneurship at the macrolevel, EIM Research Reports, https://core.ac.uk/download/pdf/6480306.pdf (dostęp: 30.07.2017).

Kaźmierczak T. (2007). „Zrozumieć ekonomię społeczną", w: T. Kaźmierczak, M. Rymsza (red.), Kapitał społeczny. Gospodarka społeczna (s. 93-126). Warszawa: Fundacja Instytut Spraw Publicznych.

Kerlin J.A. (2013). „Defining social enterprise across different contexts: A conceptual framework based on institutional factors", Nonprofit and Voluntary Sector Quarterly, Vol. 42(1), s. 84-108.

Kerlin J.A. (2017). Shaping social enterprise: Understanding institutional context and influence. Bingley: Emerald Publishing Limited. i ekonomicznych oraz ukazanie wagi relacji zachodzących pomiędzy nimi skłaniają do wykorzystania wybranych teorii z jej dorobku do badania przedsiębiorczości społecznej. Jest to tym bardziej zasadne w kontekście skromnych (krajowych) doświadczeń związanych z wyjaśnianiem PS na gruncie teorii ekonomicznych, a także udanych prób podjętych w tym zakresie przez badaczy zagranicznych [np. Urbano, Toledano, Soriano, 2010; Estrin, Mickiewicz, Stephan, 2013].

Konecki K.T. (2000). Studia z metodologii badań jakościowych. Teoria ugruntowana, Wydanie I. Warszawa: Wydawnictwo Naukowe PWN.

Lehner O.M. (2012). Social Entrepreneurship Perspectives. Triangulated Approaches to Hybridity. Jyväskylä: Jyväskylä Studies in Business and Economics.

Leś E. (2001). Zarys historii dobroczynności i filantropii w Polsce. Warszawa: Prószyński i S-ka.

Leś E. (2005). „Nowa ekonomia społeczna. Wybrane koncepcje", Trzeci Sektor, nr 2, s. 36-44.

Leś E. (2006). „Wprowadzenie”, w: M. Ołdak, E. Leś (red.), Z teorii i praktyki gospodarki społecznej (s. 5-14), Tom 1. Warszawa: Collegium Civitas Press.

Leś E. (2008). „Gospodarka społeczna i przedsiębiorstwo społeczne. Przegląd koncepcji i dobrych praktyk", w: E. Leś (red.), Gospodarka społeczna i przedsiębiorstwo społeczne. Wprowadzenie do problematyki (s. 37-56). Warszawa: Wydawnictwa Uniwersytetu Warszawskiego.

Leś E. (2013). Organizacje non profit w nowej polityce społecznej w Polsce na tle europejskim. Warszawa: Oficyna Wydawnicza ASPRA-JR.

Małecka-Łyszczek M. (2017). Współpraca administracji publicznej z podmiotami ekonomii społecznej. Aspekty prawnoadministracyjne. Warszawa: Wolters Kluwer.

Manifest Ekonomii Społecznej (2008). Gdańsk, www.ekonomiaspoleczna.pl/files/ekonomiaspoleczna.pl/public/manifest_ekonomii_spolecznej.pdf (dostęp: 20.05.2017)

Piechowski A. (2008). „Gospodarka społeczna i przedsiębiorstwo społeczne w Polsce. Tradycja i przykłady", w: E. Leś (red.), Gospodarka społeczna iprzedsiębiorstwo społeczna. Wprowadzenie do problematyki (s. 13-36). Warszawa: Wydawnictwa Uniwersytetu Warszawskiego.

Piechowski A. (2013). „Wkład spółdzielczości w odzyskanie niepodległości", w: T. Skoczek (red.), Spółdzielczość w budowie społeczeństwa obywatelskiego - histo- 
ria i współczesność (s. 49-62). Warszawa: Muzeum Niepodległości w Warszawie.

Płonka M. (2015). „Ekonomia społeczna a koncepcje polityki społecznej państwa", Ekonomia Społeczna, nr 2, s. 85-100.

Praszkier R., Zabłocka-Bursa A., Józwik E. (2014). Social Enterprise, Social Innovation and Social Entrepreneurship in Poland: A National Report. University of Warsaw, EFESEIIS, www.fp7-efeseiis.eu/nationalreport-poland (dostęp: 30.07.2018).

Roy M.J., McHugh N., Huckfield L., Kay A., Donaldson C. (2015). "The most supportive environment in the world'? Tracing the development of an insttutional'ecosystem' for social enterprise", Voluntas, vol. 26(3), s. 777-800

Rymsza A. (2010). "Wstęp do wydania polskiego”, w: J. Mair, J. Robinson, K. Hockerts (red.), Przedsiębiorczość społeczna (s. 9-12). Warszawa: Wydawnictwo Wyższej Szkoły Pedagogicznej TWP w Warszawie.

Rymsza M. (2007a). „Druga fala ekonomii społecznej w Polsce a koncepcja aktywnej polityki społecznej", w: T. Kaźmierczak, M. Rymsza (red.), Kapitał społeczny. Ekonomia społeczna (s. 175-189). Warszawa: Instytut Spraw Publicznych.

Rymsza M. (2007b). „Trzeci sektor a druga fala ekonomii społecznej w Polsce", Trzeci Sektor, nr 9, s. 2-8.

Sprawozdanie z realizacji Krajowego Programu Rozwoju Ekonomii Społecznej za okres sierpień 2014 - grudzień 2015 (2017). Warszawa: Ministerstwo Rodziny, Pracy i Polityki Społecznej.
Stronkowski P., Andrzejewska M., Łubian K., Cyran-Juraszek K., Matejczuk A. (2013). Badanie ewaluacyjne pt. Ocena wsparcia w obszarze ekonomii społecznej udzielonego ze środków EFS w ramach POKL. Warszawa: Coffey International Development.

Śliwiński A. (2013). "Spółdzielczość w Polsce w świetle ekonomii społecznej", w: T. Skoczek (red.), Spółdzielczość w budowie społeczeństwa obywatelskiego - historia i współczesność (s. 113-118), Warszawa: Muzeum Niepodległości w Warszawie.

The best countries to be a Social Entrepreneur 2016 (2016). Thomson Reuters Foundation, http:// poll2016.trust.org/ (dostęp: 30.07.2018).

Urbano D., Ferri E., Peris-Ortiz M., Aparicio S. (2017). "Social entrepreneurship and institutional factors: A literature review", w: M. Peris-Ortiz, F. Teulon, D. Bonet-Fernandez (red.), Social Entrepreneurship in Non-Profit and Profit Sectors. Theoretical and Empirical Perspectives (s. 9-30). International Studies in Entrepreneurship, vol. 36. Springer International Publishing.

Urbano D., Toledano N., Soriano D.R. (2010). „Analyzing social entrepreneurship from an institutional perspective: Evidence from Spain", Journal of Social Entrepreneurship, Vol. 1(1), s. 54-69.

Wilkin J. (2016). Instytucjonalne i kulturowe podstawy gospodarowania. Humanistyczna perspektywa ekonomii. Warszawa: Wydawnictwo Naukowe Scholar.

Zybała A. (2015). „Społeczeństwo obywatelskie i polityka publiczna", Społeczeństwo Obywatelskie. Badania. Praktyka. Polityka, nr 2 (1-2), s. 35-53.

\section{Trajectory of changes in social entrepreneurship in Poland}

Summary: The article focuses on presenting the trajectory of changes in social entrepreneurship in Poland, emphasizing the temporal and processual nature of the phenomenon. The purpose of the article is to describe the development of social entrepreneurship in the macro perspective and to identify on this basis the factors that may determine its development, thus being the subject of further theoretical reflection. The text is based on a literature inquiry in the field of social entrepreneurship and its analysis. The considerations lead to the conclusion that in the analysis of the phenomenon, historical heritage and legal and institutional factors have an important place. Thus, the role of the institutional environment as an important variable determining the development of the social entrepreneurship was indicated.

Keywords: social entrepreneurship, development, trajectory of changes, development factors, institutional environment.

\section{Prawa autorskie i licencja / Copyright and License}

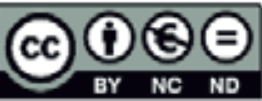

Artykuł opublikowano na licencji Creative Commons

Uznanie autorstwa - Użycie niekomercyjne - Bez utworów zależnych 3.0 Polska

http://creativecommons.org/licenses/by-nc-nd/3.0/pl/

This article is published under the terms of the Creative Commons

Attribution - NonCommercial - NoDerivs (CC BY-NGND 3.0) License

http://creativecommons.org/licenses/by-nc-nd/3.0/ 